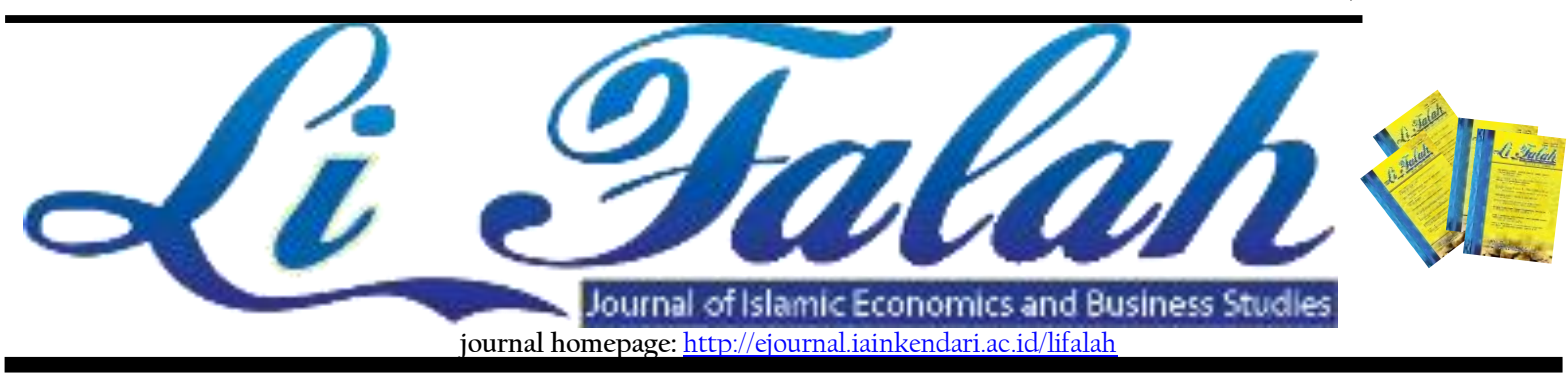

\title{
Effect of Maqashid Syariah Application on Corporate Governance in Sharia Hotels
}

\author{
Indri Yuliafitri ${ }^{1}$, Euis Nurhayati ${ }^{2}$, Gia Kardina Prima Amrina ${ }^{3}$ \\ ${ }^{123}$ Universitas Padjajaran, Indonesia

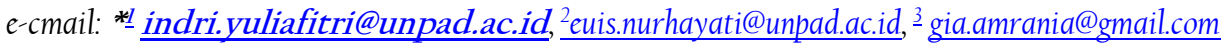

\begin{tabular}{|c|c|}
\hline ARTICLE INFO & A B S T R A C T \\
\hline Article History: & Indonesia is one of the countries with the largest Muslim \\
\hline Received 30 Mei 2020 & population globally. This issue gives Indonesia has an \\
\hline Received in lst revised form & excellent opportunity to develop the halal industry. \\
\hline 8 August 2020 & Indonesia's halal industry is still inferior when compared \\
\hline Received in 2 nd revised & to predominantly non-Muslim countries. Halal tourism, \\
\hline form 14 October 2020 & especially in this case sharia hotels, is one of the business \\
\hline Received in 3rd revised form & lines that has received significant attention in this modern \\
\hline 23 November 2020 & era. In recent years, tourism has become a different trend \\
\hline Available online 31 & for various groups, leading to a demand for travel facilities \\
\hline December 2020 & that do not conflict with Islamic values. This study aimed \\
\hline & to study the effect of the application of Maqashid Syariah \\
\hline Keywords: & on Corporate Governance in Sharia Hotels. The research \\
\hline Maqashid Syariah, & methodology used is a survey. The type of data used in this \\
\hline Corporate & study is primary data. Analysis of the data in this study was \\
\hline Governance, Sharia & using simple regression analysis. The study results show \\
\hline Hotel & that the implementation of Sharia Magashid has a \\
\hline$\frac{\text { http://dx.doi.org/10.31332/ }}{\text { lifalah.v5i2.1942 }}$ & $\begin{array}{l}\text { signiticant influence on good governance and governance } \\
\text { in sharia hotel management. }\end{array}$ \\
\hline
\end{tabular}

\section{Introduction}

Indonesia is one of the countries with the largest Muslim population globally. This fact gives Indonesia has a considerable opportunity to develop the halal industry. The Indonesian halal industry is still inferior when compared to predominantly non-Muslim countries.

But in the past few years, public awareness of the application of Islamic values in each of their daily activities has grown and developed. The phenomenon of hijrah became one of the factors that supported the growth and development of the application of Islamic values in various aspects. This issue seemed to open the way for Indonesia's halal industry to develop the sector.

In the beginning, the application of Islamic values was only limited to the financial industry. Still, now Islamic values have also begun to underlie various other business practices to a lifestyle in society. For example, fashion, cosmetics, food, and beverages to halal tourism. 
In the financial industry, especially banking, we are familiar with Islamic banking, which runs every business activity based on sharia principles. Many products are emerging, and even service provider entities are labeled halal. Ranging from cosmetic products, food, and beverages, medicines, electronic equipment to sports equipment brands that are quite well known, they also issued unique products for consumers who use hijab. As if not to be outdone, even from the non-financial services industry sector, emerging service provider entities provide services based on Islamic values, such as salons, travel, hotels, restaurants, and tourist destinations labeled sharia.

According to Yuswohady as a business observer who is also a Managing Partner Inventure, the Muslim market in Indonesia is overgrowing that the Muslim market is now a "mainstream market" in Indonesia because about $88 \%$ of Indonesia's population is Muslim and Muslim behavior is currently developing so fast and dynamic. Therefore, this is a significant opportunity for business people to build their business based on Islamic values.

Halal tourism, especially in this case sharia hotels, is one of the business lines that received considerable attention in this modern era. This opportunity is because, in recent years, tourism activities have become a distinct trend for various groups, which has led to a demand for travel facilities that do not conflict with Islamic values.

In contrast to business in general, companies that are based on Islamic values have several characteristics that are interlaced: (1) always based on ruhiyah values; (2) have an understanding of the business that is lawful and unclean; (3) correct in Syariah implementation; (4) oriented to the results of the world and the hereafter; and (5) making business as a field of worship and becoming a reward before Allah SWT (Mahmudah, N. A., 2012).

The primary key in sharia business is the halalness of a product or service offered. Halal is not limited to raw materials, sources or tools used, and systems used in management, governance, and accounting processes (recording up to the presentation of financial statements).

Some laws in Indonesia relating to State finance mandate the importance of having a foundation on sound corporate governance principles. The World Bank defines governance as a collection of laws, regulations, and rules that must be fulfilled, encouraging company resources' performance to function efficiently to generate sustainable long-term economic value for shareholders and the surrounding community whole.

According to the Minister of State-Owned Enterprises Regulation Number PER-01 / MBU / 201l, governance is the principle that underlies a process and mechanism for managing the company based on laws and business ethics. Good Corporate Governance will undoubtedly support the achievement of company goals.

Established companies and Islamic companies have different goals. If an established company is only based on profit, it is different from an Islamic company that aims to reach the maslahah of the world's success and the hereafter. Established companies will maximize shareholder wealth and increase company value to achieve their objectives. At the same time, Islamic companies achieve their goals by implementing the Maqashid Syariah principle.

Maqashid Shari'ah has five indicators: religious attainment, improving quality of life, improving the quality of science, improving the quality of offspring, and increasing wealth.

Research on applying Islamic law to corporate governance is still limited in number. Therefore the researcher intends to analyze the impact of using this Islamic sharia law on the government in sharia hotels in West Java. 


\section{Literature Review}

\subsection{Maqashid Syariah}

Maqidah shari'ah consists of two words, namely, maqashid and shari'ah. Maqashid is a plural form of maqashid that means deliberate or objective; shari'ah means the water source path. The path to this water source can also be the way to live's principal source.

According to Asy-Syatibi, maqashid shari'ah is the purpose of more shari'ah pay attention to the public interest.

As in the dictionary and its explanation that the Shari'a is the law set by Allah for His believer, or the rule set forth and ordered by Allah in the form of pray (shaum, shalat, haji, zakat, and all good deeds) or muamalah that moves human life (sell, buy, marry, etc.). Allah SWT says:

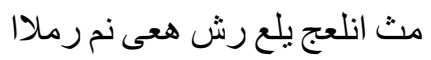

"Then We put you, [O Muhammad], on an ordained way concerning the matter [of religion]; so follow it and do not follow the inclinations of those who do not know." (QS. al- Jatsiyah:18)

According to the term, Maqashid Shari'ah is the value's content, which is the purpose of the law of syariat. So, Maqashid Shari'ah is the goal of the regularity of law.-*

Imam asy-Syathibi believes that the primary purpose of maqashid any shari'ah has three categories of law, that is :

a. Daruriyyat

According to Literally, it means urgent or emergency needs. In this category, five things need to be considered: maintaining religion, maintaining the soul, maintaining the mind, maintaining honor and descent, and maintaining property.

b. Hajiyyat

Based on literally means secondary needs. If these needs do not materialize, they do not threaten safety but will experience difficulties

c. Tashiniyyat

Based on literally, means things that make percent. The level of this need is in the form of complementary needs. If these needs are not met, it will not threaten nor cause difficulties

Maqasid Syariah, or the purpose of sharia, has a principal benefit and have five things (Jauhar, 2009), namely:

a. Hifdz ad-Din

Maintaining religion (Hifdz ad-Din) as an excuse, he was obliged to preach, pray, and jihad if one tried to destroy this religion.

b. Hifdz An-Nafs

Maintain the Spirit (Hifdz An-Nafs) as an excuse required to fulfill basic life needs (clothing, food, and board) and Perform qishash to approve of the glorious human spirit.

c. Hifdz Al-'Aql

Maintain Mind (Hifdz Al-'Aql); as an excuse, he is obliged to study all life, prohibited from consuming intoxicants and drugs.

d. Hifdz An-Nasab

Keeping the Generation (Hifdz An-Nasab); as the reason for improving the quality of generation, and forbidden Zina and relative marriage.

e. Hifdz Al-Mal

Maintain property (Hifdz $\mathrm{Al}-\mathrm{Mal}$ ); as an excuse to manage wealth, what we need makes us capable of reaching four goals are above. And prohibited theft, bribery, riba transactions, and spending other people's property. 


\subsubsection{Hotel Syariah}

The meaning of Sharia hotel is the hotel that applies Islamic sharia to hotel operations. The hotel is highlighted by management by creating a motto, logo, interior ornament, room facilities, hotel facilities, or hotel employees' uniforms.

Hotel Sharia is a hotel that operates. Its service has adapted to the principles of shari'ah or Islamic teaching guidelines to provide a peaceful, comfortable, healthy, and friendly atmosphere that guests, both Muslim and non-Muslims, need.

Hotel Syariah is an Islamic business that must be based on shari'ah values, both in service and management. Some of the things that differentiate shari'a hotels from other hotels are:

a. Food serving using halal ingredients, as well as useful for health.

This statement follows the principles of shari'ah based on the Qur'an:

Meaning: "O mankind, eat from whatever is on earth [that is] lawful and good and

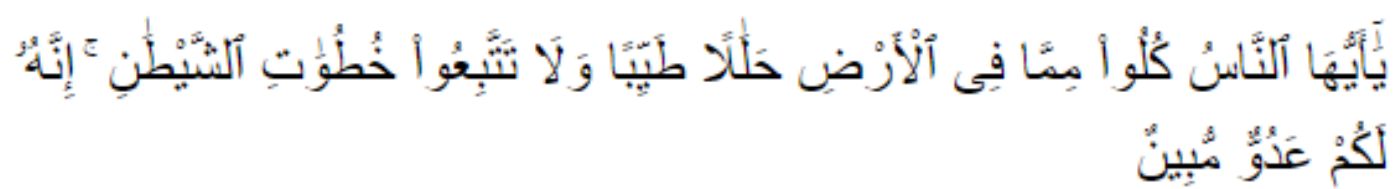

do not follow the footsteps of Satan. Indeed, he is to you a clear enemy". (Q.S. alBaqarah: 168).

b. Drinks are avoided from the alcohol content.

This alcohol is forbidden because alcohol is a toxic drink, and the law is illegal. As for the hadith of Prophet Muhammad SAW :

Meaning: Dari Ibnu Umar said: Nabi SAW said:" Every intoxicant is Khamr and every intoxicant is forbidden." (H.R. Muslim).

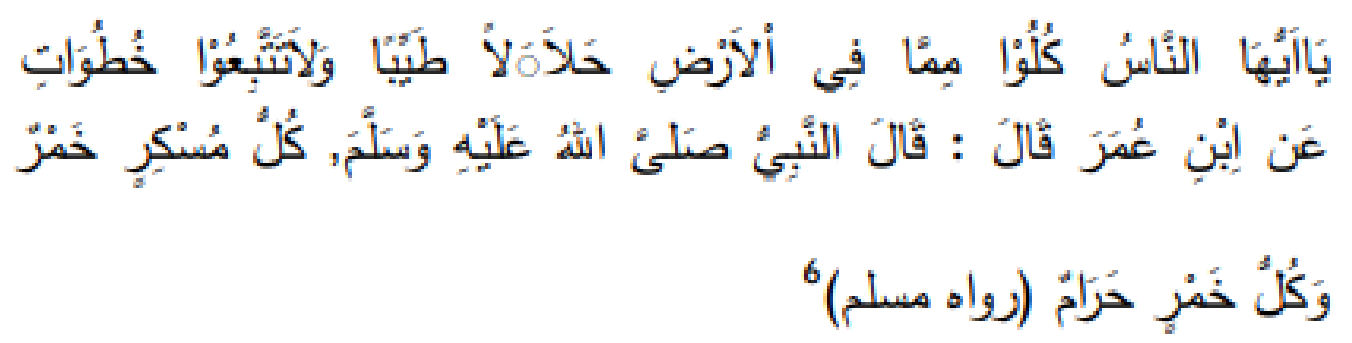

c. In the Al-Qur'an Surat al-Baqarah verse 219 Allah SWT says:

Meaning: "They ask you about wine and gambling. Say, "In them is great sin and [yet, some] benefit people. But their sin is greater than their benefit." And they ask you what they should spend. Say, "The excess [beyond needs]." Thus, Allah clarifies the verses [of revelation] that you might give thought to. (Q.S. al-Baqarah: 219)

d. Availability of prayer facilities in hotels, such as prayer rooms/mosques and prayer equipment in each room, such as mukena, prayer mats, and the Qur'an.

e. The decorations on the hotel reflect Islamic values, for example, calligraphy painting.

f. Removal of facilities that cause immorality, such as bars, discotheques, and others.

g. Selective rules for couples who stay overnight. With that rule, there was a guest selection at the hotel. But then it doesn't mean that you have to show the marriage certificate when you want to stay, but the hotel limits guests who check-in, which is not husband and wife must separate their rooms. And, with the removal of these facilities by itself, the market selection also occurred. 
DSN-MUI has regulated Sharia-based hotel standards, which are divided into two groups, namely:

a. Hotel Syariah Hilal-1

The classification for sharia hotel businesses is considered to fulfill all sharia hotel businesses needed to serve the minimal needs of Muslim tourists. In other words, fulfilling some sharia elements following the assessment of sharia hotel businesses determined by the DSN-MUI

b. Hotel Syariah Hilal-2

The classification for sharia hotel businesses that are considered to fulfill all the criteria of sharia hotel businesses needed to serve the moderate needs of Muslim tourists. It can be said that this category means fulfilling all Sharia elements following the assessment of the hotel business, which the DSN-MUI also determines

The rules must guide sharia business both in the form of orders and prohibitions, Allah SWT Berfirman :

Meaning: And [mention] the Day when We will resurrect a witness over them from

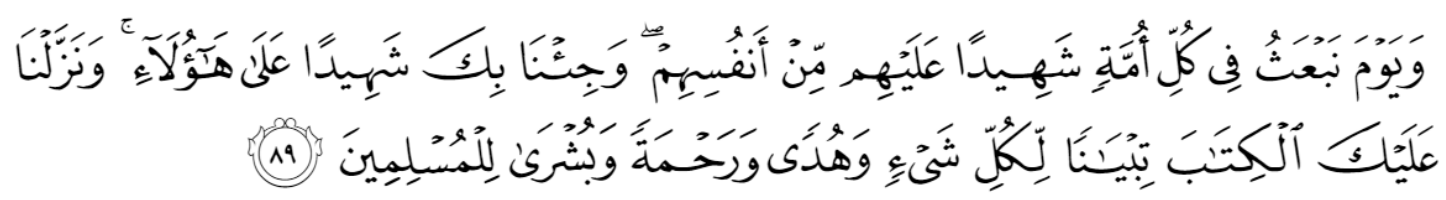

themselves among every nation. And We will bring you, [O Muhammad], as a witness over your nation. And We have sent down to you the Book as clarification for all things and as guidance and mercy and good tidings for the Muslims.

The legal basis for sharia hotels is already in the Qur'an and hadith :

a. Al-Ankabut [29] verse 20:

Meaning: Say, [O Muhammad], "Travel through the land and observe how He

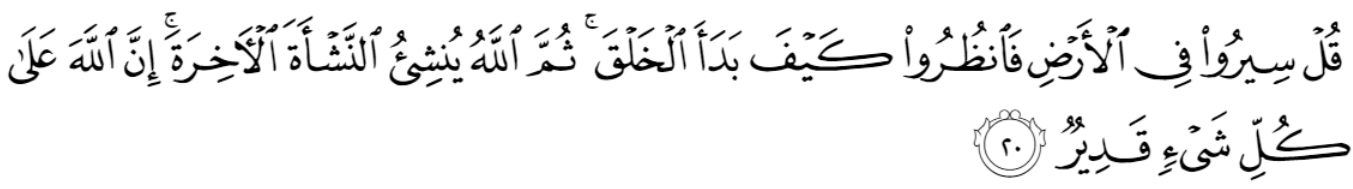

began creation. Then Allah will produce the final creation. Indeed Allah, over all things, is competent."

b. Ar-Rum [30] verse 42 :

Meaning: Say, [O Muhammad], "Travel through the land and observe how was the end

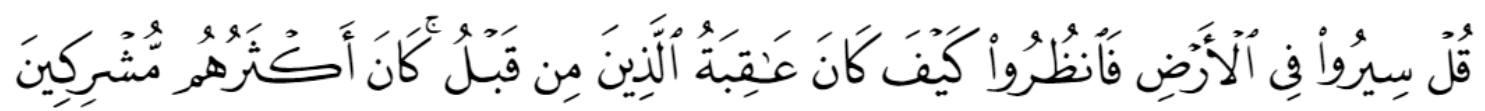

of those before. Most of them were associators [of others with Allah ].

c. Al-An'Am [6] verse 1l:

Meaning: Say, "Travel through the land; then observe how was the end of the deniers."

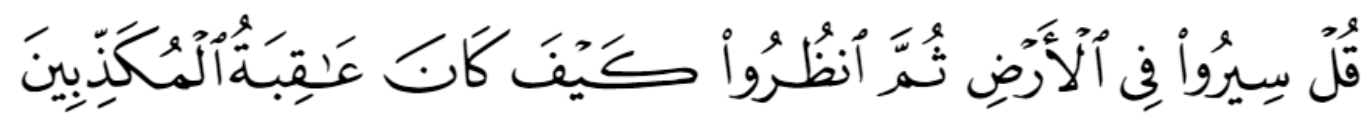




\subsubsection{Good Corporate Governance}

Good Corporate Governance is a system that regulates and controls companies that create added value for all stakeholders" (Monks: 2003). Corporate governance is defined by IICG (Indonesian Institute of Corporate Governance) as a process and structure applied in running a company, with the primary goal of increasing shareholder value in the long term and still paying attention to the interests of other stakeholders. According to FCGI (2001), the notion of Good Corporate Governance is a set of rules that govern the relationship of shareholders, managers (managers) of companies, creditors, governments, employees, and other internal and external stakeholders related to their rights and obligations or in other words a system that regulates and controls the company

After the definition and essential aspects of Good Corporate Governance are explained above, the following are discussed regarding the principles contained in Good Corporate Governance. There are five basic principles: transparency, accountability, responsibility, independence, and fairness. According to Affendi (2016) and (La Pade, 2020), these principles can be described as follows:

a. Transparency

The basic principle must provide material and relevant information in an effortless manner accessible and understood by stakeholders. The company must take the initiative to reveal the problems required by the rules and regulations and what matters to take decisions by shareholders, creditors, and other stakeholders.

b. Accountability

The basic principle, the company must be able to account for its performance transparently and fairly. For that company, it must be managed correctly, measurable, and consistent with the firm's interests take into account other parts. Accountability is a prerequisite needed to achieve sustainable performance.

c. Responsibility

Basic principles, companies must be able to comply with legislation and carry out responsibility for society and the environment to maintain business continuity in the long run and earn recognition as good corporate governance.

d. Independence (independence)

The basic principle is that the company must be managed independently so that each company's entity is not mutually exclusive dominant and can not be intervened by others.

e. Fairness (Equality and Fairness)

In carrying out its activities, the basic principle is that the company should always pay attention to the interests of shareholders and stakeholders, others based on the principle of equality and fairness. 


\subsubsection{Framework}

Based on the literature review, this study's framework uses Maqashid Syariah's theory to assess good corporate governance in Sharia hotels.

The literature review analyzes scientific sources on a specific topic in the last ten years that correspond to the research topic. Present the issues and actual scientific debates critically in the research topic and determine the existing research's research position. Review literature can be arranged chronologically, thematically, methodologically, and theoretically.

\section{Data and Research Method}

This research is quantitative research that aims to determine the effect of Maqashid Syariah's application on Corporate Governance in Sharia Hotels in West Java. The object of this research is hotel sharia, located in West Java. The data source of this study is the primary data source; the company that became the sample in this study was a Sharia Hotel located in West Java

\section{Result}

\begin{tabular}{lrrrrr}
\hline & Table l. Residuals Statistics & & \\
& $\begin{array}{c}\text { Minimu } \\
\mathrm{m}\end{array}$ & $\begin{array}{c}\text { Maximu } \\
\mathrm{m}\end{array}$ & \multicolumn{1}{c}{ Mean } & $\begin{array}{c}\text { Std. } \\
\text { Deviation }\end{array}$ & $\mathrm{N}$ \\
\hline Predicted Value & 78.2482 & 96.6505 & 86.7826 & 7.21995 & 23 \\
\hline Std. Predicted Value & -1.182 & 1.367 & .000 & 1.000 & 23 \\
\hline $\begin{array}{l}\text { Standard Error of Predicted } \\
\text { Value }\end{array}$ & 1.523 & 2.606 & 2.108 & .404 & 23 \\
\hline Adjusted Predicted Value & 76.7204 & 96.8936 & 86.7362 & 7.23222 & 23 \\
\hline Residual & 12.31526 & 12.75178 & .00000 & 7.10667 & 23 \\
& -1.693 & 1.753 & .000 & .977 & 23 \\
\hline Std. Residual & -1.755 & 1.855 & .003 & 1.014 & 23 \\
\hline Stud. Residual & - & 14.27955 & .04639 & 7.66128 & 23 \\
\hline Deleted Residual & 13.23572 & 1.980 & .002 & 1.045 & 23 \\
\hline Stud. Deleted Residual & -1.854 & 1.868 & .957 & .707 & 23 \\
\hline Mahal. Distance & .009 & .206 & .039 & .049 & 23 \\
\hline Cook's Distance & .000 & .000 & .043 & .032 & 23 \\
\hline Centered Leverage Value & & & & & \\
\hline \multicolumn{1}{c}{ a. Dependent Variable: GCG } & & & & & 23 \\
\end{tabular}

Table 2. Variables Entered/Removed

\begin{tabular}{llll}
\hline Model & Variables Entered & $\begin{array}{l}\text { Variables } \\
\text { Removed }\end{array}$ & Method \\
\hline $1 \quad \begin{array}{l}\text { Implementasi } \\
\text { Maqashid Syariah }\end{array}$ & & Enter \\
\hline a. Dependent Variable: GCG & \\
\hline b. All requested variables entered. & \\
\hline
\end{tabular}




\begin{tabular}{|c|c|c|c|c|c|}
\hline \multicolumn{6}{|c|}{ Table 3. Model Summary } \\
\hline Model & $\mathrm{R}$ & R Square & $\begin{array}{l}\text { Adjusted R } \\
\text { Square }\end{array}$ & $\begin{array}{l}\text { Std. error of the } \\
\text { Estimate }\end{array}$ & Durbin-Watson \\
\hline 1 & $.713^{\mathrm{a}}$ & .508 & .484 & 7.27391 & 1.801 \\
\hline \multicolumn{6}{|c|}{ a. Predictors: (Constant), Implementasi Maqashid Syariah } \\
\hline \multicolumn{6}{|c|}{ b. Dependent Variable: GCG } \\
\hline
\end{tabular}

Based on the table above, it can be seen that the correlation coefficient value is 0.713 , then the coefficient of determination (R2) obtained a value of 0.508 . This data means an influence between maqashid sharia on good corporate governance of $50.8 \%$. In comparison, the remaining $49.2 \%$ is influenced by other variables that the researchers did not involve in this study.

\begin{tabular}{llrrrrr}
\hline \multicolumn{7}{c}{ Table 4. ANOVA } \\
\hline \multirow{2}{*}{1} & Model & Sum of Squares & df & Mean Square & F & \multicolumn{1}{c}{ Sig. } \\
\cline { 2 - 7 } & Regression & 1146.809 & 1 & 1146.809 & 21.675 & $.000^{\mathrm{b}}$ \\
\cline { 2 - 7 } & Residual & 1111.104 & 21 & 52.910 & & \\
\cline { 2 - 7 } & Total & 2257.913 & 22 & & & \\
\hline
\end{tabular}
a. Dependent Variable: GCG
b. Predictors: (Constant), Implementasi Maqashid Syariah

From the table above, it is known that F-count is 21,675 . Then the significance value (sig. $0,000)$ when compared between significance values ( $\mathrm{sig})$ with alpha value $(\alpha=0.05)$, then the significance value is smaller than alpha value, meaning maqashid sharia and good corporate governance have a significant influence. Then test the hypothesis with the F test, with the following conditions:

- If $\mathrm{F}$-count $>\mathrm{F}$-table, then $\mathrm{HO}$ is rejected and $\mathrm{Hl}$ is accepted, which means that there is a significant influence between variable maqashid Syariah towards good corporate governance

- If $\mathrm{F}$-count $<\mathrm{F}$-table, then $\mathrm{HO}$ is rejected and $\mathrm{Hl}$ is rejected, which means there is no significant influence between maqashid Syariah variables on good corporate governance

\section{Hypothesis:}

$\mathrm{H}_{0}$ : There is no significant influence of Islamic maqashid on good corporate governance $\mathrm{H}_{1}$ : There is a significant influence of Syariah maqashid on good corporate governance

Based on the conditions stated above, where the F-table is 4.35 while F-count is 21.675 , so $\mathrm{F}$-count> $\mathrm{F}$ - the table means that $\mathrm{HO}$ is rejected and $\mathrm{Hl}$ is accepted, meaning that there is a significant influence between maqashid sharia on good corporate governance

Table 5. Coefficients

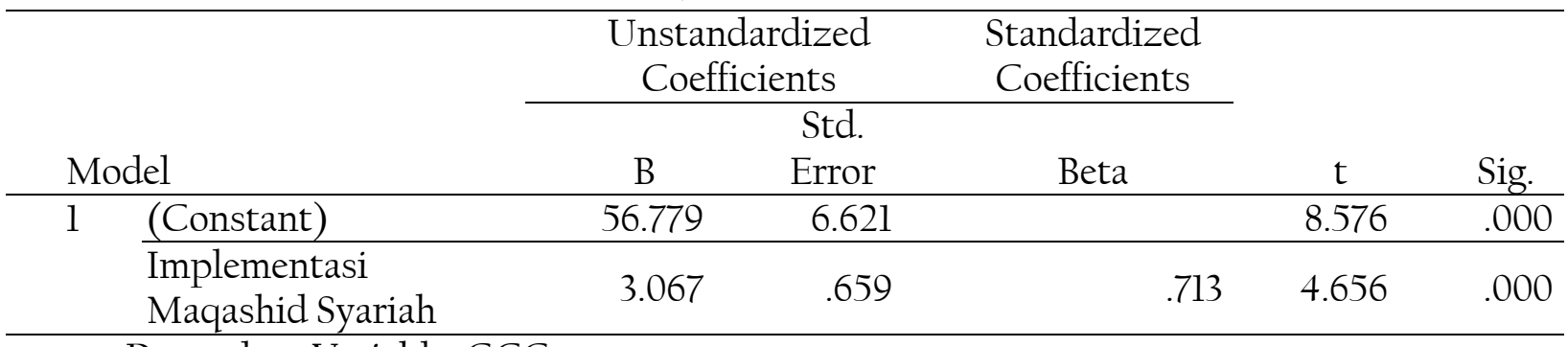

a. Dependent Variable: GCG 
Based on the results of calculations in the table above, obtained the form of simple linear regression equations as follows:

$$
\mathrm{Y}=56.779+3.067 \mathrm{X}
$$

The regression coefficient value in the independent variable illustrates that if it is estimated that the separate variable rises by one unit, then the value of the dependent variable can be expected to rise or go down following the sign of the regression variable of the independent variable.

The independent variable regression coefficient shows the direction of Maqashid Syariah's correlation with the Good Governance Regression coefficients for independent variables are positive, indicating a unidirectional relationship between Maqashid Syariah (X) and Good Corporate Governance (Y). The regression coefficient of variable X of 3,067 means that each addition of maqashid sharia $(X)$ of one unit will cause an increase in good corporate governance (Y) of 3,067 units

The hypothesis using the $t$-test which has the following conditions :

- If $\mathrm{t}$ count $>\mathrm{t}$ table, $\mathrm{HO}$ is in the rejection area, meaning $\mathrm{Hl}$ is accepted or influenced.

- If $\mathrm{t}$ count $\mathrm{t}$ table, then $\mathrm{HO}$ is in the accepted area, meaning $\mathrm{Hl}$ is rejected or has no influence.

\section{Hypothesis:}

$\mathrm{H}_{0}$ : There is no significant influence of Islamic maqashid on good corporate governance $\mathrm{H}_{1}$ : There is a significant influence of Syariah maqashid on good corporate governance

Based on the earlier provisions, where $t$-count of 4,656 and the number $t$ table is 2.08506 , so $t$-count $>\mathrm{t}$-table. This information means that $\mathrm{HO}$ is rejected and $\mathrm{Hl}$ is accepted, so there is a significant influence of maqashid sharia on good corporate governance. Thus the hypothesis states that there is a substantial influence of maqashid sharia on good corporate governance.
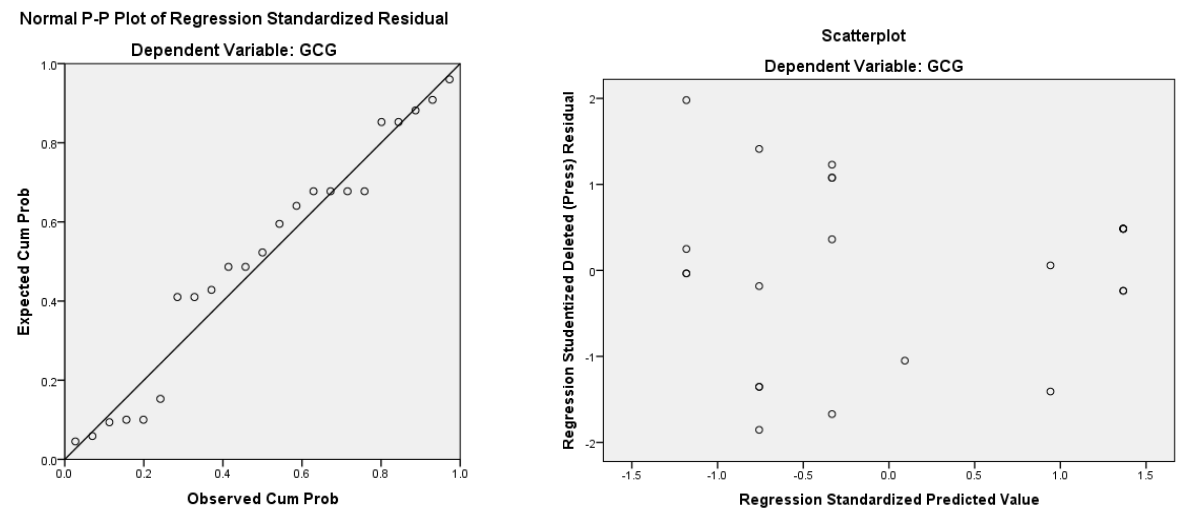

Image 1. Scatterplot

From the scatterplot above, it can be seen that the points spread and did not form specific patterns. So it can be concluded that there is no problem with heteroscedasticity. 


\section{Summary}

Based on the analysis and result, it can be concluded, this study's goal is to measure good corporate governance by using Maqashid Syariah. From the above research results, it can be concluded that Sharia maqashid's implementation has a significant influence on good corporate governance in sharia hotel management.

\section{Reference}

Audah, J. 2013. Al Maqashid untuk Pemula. Yogyakarta: Suka Press.

Birton, M. N. A., (2015). Maqashid Syariah sebagai Metode Membangun Tujuan Laporan Keuangan Entitas Syariah. Jurnal Akuntansi Multiparadigma, Vol. 6, No. 3, Hlmn. 421431.

Daniri, Mas Achmad. 2014. Lead By GCG. Gagas Bisnis Indonesia. Jakarta.

Janitra, Muhammad Rayhan. 2017. Hotel Syariah: Konsep dan Penerapan. Depok: PT. Rajagrafindo Persada.

Mahmudah, N. A., (2012). Pengawasan Terhadap Bisnis Syariah di Indonesia. Economic: Jurnal Ekonomi dan Hukum Islam, Vol. 2, No. 2.

Mohammed, M. O., and F. M. Taib. 2009. Testing the Performance Measured Based on Maqashid Framework Shariah (PPMS). Model on 24 Selected Islamic and Conventional Bank. Dipublikasikan. Paper. International Islamic University of Malaysia (IIUM).

Accounting and Auditing Organization for Islamic Financial Institutions (AAOIFI). (2001). Accounting, Auditing, and Governance Standards for Islamic Financial Institution. AAOIFI. Bahrain.

IAI, 2007b, Standar Akuntansi Keuangan, Kerangka Dasar Penyusunan dan Penyajian Laporan Keuangan Syariah. Salemba Empat, Jakarta.

La Pade, A. (2020). Kinerja Portofolio Saham Syariah dan Faktor yang Memengaruhi Kinerja Saham Syariah di Indonesia. 5(1), 17-41. https://doi.org/http://dx.doi.org/10.31332/lifalah.v5il.1884

Shidiq, G. 2009. Teori Maqashid Syariah dalam Hukum Islam. Universitas Islam Sultan Agung, XLIV (188). 